\title{
Influence of Self-Esteem in the Withdrawal EPS Students from Catholic Schools of Humanities in Kinshasa
}

\author{
Aristide Ewamela1, Paulin Mandoumou'1, Agnes Kena Lubika², Euloge Moboza Ndongo ${ }^{3}$, \\ Joachim Bongbele ${ }^{1}$ \\ ${ }^{1}$ Teaching Laboratory for Physical Activities and Sports, Higher Institute of Physical Education from the \\ University Marien Ngouabi, Brazzaville, Congo \\ ${ }^{2}$ Department of Physical Education and Sports Management, Faculty of Sciences, National Pedagogical \\ University, Kinshasa, Democratic Republic of Congo \\ ${ }^{3}$ Teaching Staff of the Information Technologies and Communication and Sports Management, Higher Institute \\ of Physical Education of the University Marien Ngouabi, Brazzaville, Congo \\ Email: mandpaulin@yahoo.fr
}

Received 3 June 2016; accepted 8 August 2016; published 11 August 2016

Copyright (C) 2016 by authors and Scientific Research Publishing Inc.

This work is licensed under the Creative Commons Attribution International License (CC BY). http://creativecommons.org/licenses/by/4.0/

(c) (i) 0pen Access

\begin{abstract}
In order to examine the influence of self-esteem on the disengagement of students in EPS, 305 girls and 456 boys from Catholic schools of humanities (experimental group), 116 girls and 133 boys from consular schools (control group) have answered the questionnaire from Ninot et al. (2000). The averages of the two groups were compared using student test. The results showed that subjects in the experimental group showed low values of global self-esteem, the physical value, strength, endurance and athletic competence. These results indicate a parallel disengagement significantly remarkable EPS for girls and boys in the experimental group compared to their counterparts in the control group. These results suggest that the low value of self-esteem is the disengagement factor in EPS within Catholic schools of humanities in Kinshasa.
\end{abstract}

\section{Keywords}

Teaching EPS, Self-Esteem, Withdrawal EPS, Students of Humanities Catholic School Kinshasa

\section{Introduction}

\subsection{Problems}

Psychological factors related to the motivational approach are determined by the expectation of skills in general

How to cite this paper: Ewamela, A., Mandoumou, P., Lubika, A. K., Ndongo, E. M., \& Bongbele, J. (2016). Influence of Self-Esteem in the Withdrawal EPS Students from Catholic Schools of Humanities in Kinshasa. Advances in Physical Education, 6, 235-246. http://dx.doi.org/10.4236/ape.2016.63025 
and self-esteem, in particular. Self-esteem is internal to self-assessment criteria that can be improved and protected.

The increase or the protection of self-esteem seems to be the ultimate goals in which service is implemented through the attributional self-indulgence (Famose \& Guerin, 2002). Indeed, individual differences in self-esteem affect the trend toward either high or low levels of self esteem. It has been shown here that students with high value of self-esteem and low self-esteem value have different motivational orientations (Baumeister et al., 1989). This is perceptible through scientific evidence that the subjects with low value of self-esteem are more concerned with protection strategies while those with a high value of self-esteem wear of self-development strategies (Ctbt \& Baumetter, 1990).

\subsection{Research Question}

In consideration of this fact, there is reason to question generally as follows: She has self-esteem influence the disengagement EPS among students of Humanities Catholic School Kinshasa?

\subsection{Hypothesis}

The hypothesis of this study is that: the value of self-esteem influences the disengagement EPS among fifth grade students of Humanities of Kinshasa.

\subsection{Objectives}

The objectives of this study are:

1) Assess the global self-esteem, physical and athletic skill value among students of Humanities Kinshasa.

2) Identifying absences to determine the EPS disengagement level among students of Humanities Kinshasa.

3) Consider the influence of self-esteem on the disengagement EPS among students of Humanities Kinshasa.

\subsection{Interest of the Study}

This study helps to raise awareness of the disengagement in EPS which is dependent on the low value of selfesteem.

\section{Methods}

\subsection{Subjects}

\section{Characteristics}

The study focused on students of the humanities in particular literary sections (Latin-Philosophy), science (Mathematics, Physics and Biochemistry) subject to PE lessons with hourly volumes and reduced weekly frequencies (45 or 50 minutes as we 'have noted) constituting the experimental group and those in the Education section Physics College Saint Pierre, consular schools (Lycée Prince de Liège, French School, the International School Turko-Congolaise SAFAC, English International School), subject to lessons of Sports and Physical Education with the social practices of reference require hourly volumes and higher weekly frequencies (3 hours and three times at least) forming in turn the control group. These topics were selected according to the criteria of regularity during EPS, receiving, delivery of the questionnaire and the answer to all questions.

\subsection{Sampling Procedures}

The retention of these subjects was made according to the non-probability mode. He acted sampling suitable volunteers for research in psychological learning.

\section{Taille Sample}

The study of 305 girls and 456 boys in their final year of Humanities Catholic School Kinshasa (experimental group) and 116 girls and 133 boys consular schools and the Physical Education section of the Catholic school Kinshasa (control group).

\subsection{Measures and Variables}

It consisted of two parts, namely: pre investigation and the investigation itself. 
Pre investigation through the ventilation 132 questionnaires to students of humanities Kinshasa Catholic schools and secondary schools Belgian, French, Turkish-Congolese and English International School from 20 to 28 February 2013. This allowed to assess the variables of our study, grouping items of self-esteem evaluation questionnaire by component with respective Cronbach coefficients (overall self esteem with eight items (Ninot et al., 2000); $\alpha=0.90198545$, physical measured value through five items; $\alpha=0.86608582$, Force consists of four items; $\alpha=0.84825891$, Endurance assessed by five items; $\alpha=0.86608582$, athletic competence appreciated from six items; $\alpha=0.88445043$ ) and checked the hypothetical links the observed variables to out the best internal consistency which was therefore the validity of the evaluation questionnaire esteem in above establishments.

The survey was conducted from 15 April to 15 May 2013. It consisted of: present students in classrooms, at the time of EPS, the evaluation questionnaire of self-esteem with a series of statements that these students were invited to these statements carefully to indicate their degree of acceptance of different claims proposed putting a cross in the appropriate box on the scale from 1 to 6 for positive items and 6 to 1 for the negative items.

\section{Research Design}

This study was transversal compared to the extent that the subjects of two independent groups were interviewed only once.

\subsection{Statistical Data Processing}

Although this qualitative study early, the questionnaires were analyzed by considering the Likert scale (SalesWuillemin, 2006) by the transformation of qualitative values into quantitative values. The averages of the two groups were compared by use of Student's t test.

\section{Results}

Table 1 includes global self-esteem values, physical value, strength, endurance, athletic competence and Physical education demotivation among female students of the experimental and control groups in terms of average and standard deviation $(\bar{x} \pm \delta)$.

Table 1 reveals that the female students in the control group had significantly higher values of the global self-esteem, physical value, strength, endurance and athletic skill compared to their sex peers in the experimental group $(P<0.001)$. However, the value of the Physical education demotivation of female students in the experimental group was significantly greater than that of their colleagues in the control group $(P<0.001)$.

The values of the estimated overall self, physical value, strength, endurance, athletic competence and Physical education demotivation among male students of the experimental and control groups are shown in Table 2 in terms of average and standard deviation $(\bar{x} \pm \delta)$.

Like female students, male students in the control group had significantly higher values of global self-esteem, the physical value, strength, endurance and athletic competence compared to those of the experimental group ( $P$ $<0.001)$. But the Physical education demotivation value of male students in the experimental group was significantly higher compared to that of their colleagues in the control group $(P<0.001)$.

Table 1. The global self-esteem, physical value, strength, endurance, athletic skill and physical education demotivation of the female students of experimental groups and average as witness and standard deviation $(\bar{x} \pm \delta)$.

\begin{tabular}{ccccc} 
& Experimental group & Control group & \multicolumn{2}{c}{ Significance } \\
\cline { 2 - 5 } & $\mathbf{( n = 3 0 5 )}$ & $\mathbf{( n = 1 1 6 )}$ & $\mathbf{T}$ & $\boldsymbol{P}$ \\
\hline Global self-esteem & $37.82 \pm 2.52$ & $40.40 \pm 1.40^{* * *}$ & 13.28 & $<0.001$ \\
Physical value & $15.05 \pm 1.25$ & $20.40 \pm 1.86^{* * *}$ & 28.61 & $<0.001$ \\
Strength & $11.91 \pm 3.93$ & $16.41 \pm 2.58^{* * *}$ & 18.00 & $<0.001$ \\
Endurance & $16.10 \pm 1.56$ & $20.21 \pm 1.17^{* * *}$ & 29.22 & $<0.001$ \\
Athletic skill & $19.54 \pm 1.74$ & $20.40 \pm 0.49^{* * *}$ & 7.851 & $<0.001$ \\
Disengagement & $10.02 \pm 1.26^{* * *}$ & $1.41 \pm 0.49$ & $<0.001$ \\
\hline
\end{tabular}

\footnotetext{
${ }^{* * *}$ Highly significant difference $(P<0.001)$.
} 
Table 2. Global self-esteem, physical value, strength, endurance, athletic skill and Physical education demotivation male students of the experimental and control groups in terms of average and standard deviation $(\bar{x} \pm \delta)$.

\begin{tabular}{ccccc} 
& Experimental group & Control group & \multicolumn{2}{c}{ Significance } \\
\cline { 2 - 5 } & $(\mathbf{n}=\mathbf{4 5 6})$ & $(\mathbf{n}=\mathbf{1 3 3})$ & T & \multicolumn{1}{c}{$\boldsymbol{P}$} \\
\hline Global self esteem & $24.70 \pm 2.44$ & $36.64 \pm 0.76^{* * *}$ & 30.49 & $<0.001$ \\
Physical value & $21.86 \pm 1.38$ & $27.72 \pm 1.74^{* * *}$ & 160.13 & $<0.001$ \\
Strength & $13.44 \pm 1.21$ & $20.74 \pm 1.65^{* * *}$ & 4.42 & $<0.001$ \\
Endurance & $17.18 \pm 1.57$ & $25.59 \pm 2.41^{* * *}$ & 4.73 & $<0.001$ \\
Sportive skill & $15.83 \pm 4.34$ & $21.13 \pm 2.67^{* * *}$ & 17.20 & $<0.001$ \\
Demotivation & $7.93 \pm 1.25^{* * *}$ & $0.64 \pm 0.76$ & 82.7 & $<0.001$ \\
\hline
\end{tabular}

${ }^{* * *}$ Highly significant difference $(P<0.001)$.

It appears from Table 3 that female students from control group show a high global self-esteem, physical value, endurance, and sport competence in comparison to their sex peers in the experimental group $(P<0.001)$. Yet, the Physical education demotivation value is significantly higher for girls of experimental group than that control group $(P<0.001)$.

The global self-esteem value, physical value, strength, endurance, sport competence, and the physical education demotivation of male students for control and experimental groups are presented in the following Table 4 in terms of average and standard deviation $(\bar{x} \pm \delta)$.

Like for female students, male students of control group have a significantly higher value of global self-esteem, physical value, strength, endurance, sportive competence compared to their sex peers in the experimental group $(P<0.001)$. But, the Physical education demotivation of male students in the experimental group is significantly higher than that of their male colleagues in the control group $(P<0.001)$.

The global self-esteem value, physical value, strength, endurance, athletic competence, and the Physical education demotivation of girls and boys are elaborated in Table 5 in terms of average and standard deviation $(\bar{x} \pm$ $\delta$ ).

Table 5 demonstrates that female of control group has a significantly higher global self-esteem value compared to male results in the same group $(P<0.001)$. But, in the control group, physical value, strength, endurance, athletic skills, are significantly higher for male students than for female $(P<0.001)$. However, demotivation is more significant for girls in the control group than for boys in the same group $(P<0.001)$.

The global self-esteem, physical value, strength, endurance, athletic skill and Physical education demotivation of the female and male students of experimental group in terms of average and standard deviation $(\bar{x} \pm \delta)$ in Table 6.

It transpires from Table 6 that female students show a significantly higer global self-esteem value than that of male in the same group $(P<0.001)$. But, physical value, strength, endurance are significantly higher for male students than female in the same group $(P<0.001)$.

Moreover, athletic competence and Physical education demotivation are significantly higher for female in the experimental group compared to male in the same group $(P<0.001)$.

\section{Discussion}

Self-esteem is the idea of a subject in relation to its ability to perform a motor task that is the case in EPS (Famose \& Bertsch, 2009). It is marked by body size and physical dimension (including the physical value, the physical qualities and athletic skill). The overall self esteem is significantly higher among girls in the control group compared to their same-sex peers in the experimental group ( $40.40 \pm 1.40$ vs. $37.82 \pm 2.52 ; P<0.001)$ (Table 1). These results reflect a low level of global self-esteem of girls in the experimental group which is explained by the presentation of a depression, any agreement of positive attributes by them, blame that they are following the failure, their self destruction and uncertainty in the acts posed by them (Troadec, 2002).

The low value of the estimated overall self girls in the experimental group is determined by the overall appearance of the body, poor appreciation of the subject and by concern morphological changes and a low selfesteem. It is also related to age, self awareness and overall physical health. It has been generally established that 
Table 3. The global self-esteem, physical value, strength, endurance, athletic skill and physical education demotivation of the female and male students of experimental groups in terms of average and standard deviation $(\bar{x} \pm \delta)$.

\begin{tabular}{ccccc}
\hline & Experimental group & \multicolumn{2}{c}{ Control group } & \multicolumn{2}{c}{ Significance } \\
\cline { 2 - 5 } & $(\mathbf{n}=\mathbf{3 0 5})$ & $\mathbf{( n = 1 1 6 )}$ & $\mathbf{T}$ & $\boldsymbol{P}$ \\
\hline Global self-esteem value & $37.82 \pm 2.52$ & $40.40 \pm 1.40^{* * *}$ & 1328 & $<0.001$ \\
Physical value & $15.05 \pm 1.25$ & $20.40 \pm 1.86^{* * *}$ & 28.61 & $<0.001$ \\
Force & $11.91 \pm 3.93$ & $16.41 \pm 2.58^{* * *}$ & 18.00 & $<0.001$ \\
Endurance & $16.10 \pm 1.56$ & $20.21 \pm 1.17^{* * *}$ & 29.22 & $<0.001$ \\
Sportive skill & $19.54 \pm 1.74$ & $20.40 \pm 0.49^{* * *}$ & 7.851 & $<0.001$ \\
Demotivation & $10.02 \pm 1.26^{* * *}$ & $1.41 \pm 0.49$ & $<0.001$ \\
\hline
\end{tabular}

${ }^{* * *}$ Highly significant difference $(P<0.001)$.

Table 4. The global self-esteem, physical value, strength, endurance, athletic skill and physical education demotivation of the male students of experimental groups in terms of average and standard deviation $(\bar{x} \pm \delta)$.

\begin{tabular}{ccccc} 
& Experimental group & Control group & \multicolumn{2}{c}{ Significance } \\
\cline { 2 - 5 } & $\mathbf{( n = 4 5 6 )}$ & $(\mathbf{n}=\mathbf{1 3 3})$ & T & \multicolumn{1}{c}{ P } \\
\hline Global self-esteem & $24.70 \pm 2.44$ & $36.64 \pm 0.76^{* * *}$ & 30.49 & $<0.001$ \\
Physical value & $21.86 \pm 1.38$ & $27.72 \pm 1.74^{* * *}$ & 160.13 & $<0.001$ \\
Strength & $13.44 \pm 1.21$ & $20.74 \pm 1.65^{* * *}$ & 4.42 & $<0.001$ \\
Endurance & $17.18 \pm 1.57$ & $25.59 \pm 2.41^{* * *}$ & 4.73 & $<0.001$ \\
Sportive competence & $15.83 \pm 4.34$ & $21.13 \pm 2.67^{* * *}$ & 17.20 & $<0.001$ \\
Demotivation & $7.93 \pm 1.25^{* * *}$ & $0.64 \pm 0.76$ & 82.7 & $<0.001$ \\
\hline
\end{tabular}

\footnotetext{
${ }^{* * *}$ Highly significant difference $(P<0.001)$.
}

Table 5. The global self-esteem, physical value, strength, endurance, athletic skill and physical education demotivation of the female and male students of control group in terms of average and standard deviation $(\bar{x} \pm \delta)$

\begin{tabular}{cccccc} 
& \multicolumn{2}{c}{ Control group } & \multicolumn{2}{c}{ Significance } \\
\cline { 2 - 3 } & Girls & Boys & \multicolumn{2}{c}{ t } & P \\
Global self-esteem & $(\mathbf{n}=\mathbf{1 1 6})$ & $\mathbf{( n = 1 3 3 )}$ & 25.79 & $<0.001$ \\
Physical value & $40.40 \pm 1.40^{* * *}$ & $36.64 \pm 0.76$ & 31.92 & $<0.001$ \\
Strength & $20.40 \pm 1.86$ & $27.72 \pm 1.74^{* * *}$ & 5.5 & $<0.001$ \\
Endurance & $16.41 \pm 2.58$ & $20.74 \pm 1.65^{* * *}$ & 97.00 & $<0.001$ \\
Sportive competence & $20.21 \pm 1.17$ & $25.59 \pm 2.41^{* * *}$ & 3.11 & $<0.01$ \\
Demotivation & $20.40 \pm 0.49$ & $21.13 \pm 2.67^{* * *}$ & 9.6 & $<0.001$ \\
\hline
\end{tabular}

${ }^{* * *}$ Highly significant difference $(P<0.001)$.

Table 6. The global self-esteem, physical value, strength, endurance, athletic skill and physical education demotivation of the female and male students of experimental group in terms of average and standard deviation $(\bar{x} \pm \delta)$.

\begin{tabular}{cccccc} 
& \multicolumn{2}{c}{ Experimental group } & \multicolumn{2}{c}{ Significance } \\
\cline { 2 - 3 } & Girls & Boys & \multicolumn{2}{c}{ t } & P \\
Global self-esteem & $\mathbf{( n = 3 0 5 )}$ & $\mathbf{( n = 4 5 6 )}$ & 71.30 & $<0.001$ \\
Physical value & $37.82 \pm 2.52^{* * *}$ & $24.70 \pm 2.44$ & 138.97 & $<0.001$ \\
Strength & $15.05 \pm 1.25$ & $21.86 \pm 1.38^{* * *}$ & 6.59 & $<0.001$ \\
Endurance & $11.91 \pm 3.93$ & $13.44 \pm 1.21^{* * *}$ & 13.703 & $<0.001$ \\
Sportive competence & $16.10 \pm 1.56$ & $17.18 \pm 1.57^{* * * *}$ & 16.40 & $<0.001$ \\
Demotivation & $19.54 \pm 1.74^{* * *}$ & $15.83 \pm 4.34$ & 11.76 & $<0.001$ \\
\hline
\end{tabular}

\footnotetext{
${ }^{* * *}$ Highly significant difference $(P<0.001)$.
} 
the self-esteem of all adolescent girls is an important factor in the construction of Self. It correlates positively to health, appearance and overall physical self-awareness (Tetard et al., 2004). These authors attributed the low value of self-esteem with age. According to these authors the global self-esteem is judged subjectively and practiced by girls pre and post pubertal, which poses problems for the physical and psychological integrity of these girls.

The low value of global self-esteem in girls in the experimental group in relation to the social environment results antipathetic relationships developed by them following the negative feedback provided by those around them. It is determined by the bad feeling of confidence that comes from the sense of security in relation to aspects of physical security (presence of dangerous elements that the subject can not cope), psychological safety (instability) and reporting rules (abstract, variable, inconsistent and illogical) contrary to what was reported by Vignette (2007).

This low value of global self-esteem in girls in the experimental group can also be attributed to the academic institution, incompetent teachers. Indeed, the school can not be conceived as an apparatus for producing attitudes and bodily dispositions of the students of the humanities of Kinshasa. This is due to the poverty of the teaching texts governing the EPS and lack of sense of the teaching of this discipline in the Democratic Republic of Congo.

The physical value of girls in the control group was significantly higher compared to that of girls in the experimental group (20.40 \pm 1.86 vs. $15.05 \pm 1.25 ; P<0.001)$ (Table 1$)$. These results show a low value of physical self-esteem of girls in the experimental group that can be attributed to age, social environment. Age determines the physical value of girls. Indeed, it is more important to childhood and declines during puberty in girls in search of a social identity with behavioral disorders leading them to focus on aesthetic side, artistic, ... at the expense of sport. Neglect of sport diminishes self-esteem physics.

The social environment is responsible for the low physical self-worth. In this regard, Edwards (2002) has reported that the perception that a female subject has its own value grows as it reaches maturity and mingle with others. The social environment and gender might be the cause of the low physical value of these girls in the experimental group. It was reported here that the low levels of self-esteem in girls can result from discrimination, sexism, inequities in all areas of life, harassment, assaults, a dysfunctional family life, a lack of female role models, poor parenting skills or image the media project of Women (Edwards, Op. cit.). The lower value of the girls in the experimental group would probably linked to failures in learning in EPS. Indeed, a failure in a task (shooting Basketball) reduces the subdomain athletic skill with high importance to the subject. Estimated (Messer \& Harter, 1986).

The perception of strength capacity is significantly higher among girls in the control group than among their colleagues in the experimental group $(16.41 \pm 2.52$ vs. $11.91 \pm 3.93 ; P<0.001)$ (Table 1$)$. Thus, power capacity was reduced in the experimental group girls depending on their disapproval of the discipline, the attitude of the teacher frustrative against mostly female students. Indeed, the EPS can be experienced negative and demeaning manner. Passive reactions, refusal or protest may alternate with reactions of enthusiasm and exuberance. The fluctuation and instability of these behaviors express. This adjustment difficulties which can lead to anxiety that students are unable to regulate. And manifests the fragility of coping mechanisms and self-esteem. Moreover, the teacher of the EPS is a source of disgust and frustration, it can be for students, an area of failure that disrupts their evolution in terms of self-image and symbolic change in registration social practices (Couchot Schiex, 2014).

The low capacity force girls in the experimental group may depend on the weakness of the official texts which will inevitably impact on learning and the feeling of using the physical qualities whose strength. Indeed in these schools, there is no awareness of the importance of EPS through its aims. They should assign goals as the development of motor skills, acquire cultural elements related to sports and artistic physical activities; access to knowledge for the organization and maintenance of his physical life (EPS departmental team of Herault, (20102011). The institutional weakness has undoubtedly affect the psychological traits and negative assessment of the ability to force.

The negative assessment of the strength capacity could result from the temporal limitation of PE classes in the humanities Kinshasa. It is known that the force (as all the physical qualities) can not thrive in conditions of insufficient loading of resources in games (Derimay, 2006). It is not in fact possible to improve its possibilities of action and reaction, without the physical and human environment does not sufficiently constrain the processes involved in the development of strength. Workloads are unsuited to the possibilities of action and reaction of 
adolescents to trigger the self-adaptive processes of the body opposite to the design Billat (1998). And then the time allotted to EPS in the humanities Kinshasa does not develop this physical quality. Moreover, teachers who take care of the experimental group students are not able to manipulate the characteristics of the external load through a number of tasks goals descriptors to overcome the difficulty or increase the intensity of the situations set up in the physical and human environment of the EPS session.

The endurance of the girls in the experimental group was significantly less compared to that estimated for girls in the control group $(16.10 \pm 1.56$ vs. $20.21 \pm 1.17, P<0.001)$ (Table 1$)$. These results are certainly reflect a sedentary lifestyle is a condition in which the movements are minimized and energy expenditure is roughly equal to the energy metabolism at rest”. It reflects a zero or less Physical Activity the minimum threshold recommended AP [either the equivalent of 30 minutes a day walking to a not supported (brisk walk) at least 5 days per week] It corresponds to physically passive behavior (Thibault et al., op. cit.).

Obstacles to the practice of social and individual physical activity may also justify this low value estimation of endurance among girls in the experimental group. Here also the time of reduction of motor commitment can be a limiting factor for development of endurance. The lack of sports facilities and teaching materials affects planning, educational intervention and student learning and induces the reduced practice of APSA (Atikleme, 2002) and thus a decrease in the value of the endurance.

The athletic skill of the girls in the experimental group was significantly lower compared to that of their counterparts in the control group (19.54 \pm 1.74 vs. $20.40 \pm 0.49$; $P<0.001)$ (Table 1$)$. The lower value of sport competence of girls in the experimental group is not only linked to low educational time and motor commitment, but also to the absence of sessions of sporting activities in preparation for various school competitions. Sports activities under the framework of the sports association is the opportunity to train children to improve its performance and participate in school competitions. Indeed, the Catholic aided schools Kinshasa a deficit in sports facilities and sports equipment preventing the organization of sports activities.

However, girls in the experimental group were significantly more disengaged in EPS compared with the control group (10.02 \pm 1.26 vs. $1.41 \pm 0.49 ; P<0.001)$ (Table 1$)$. These results probably dependent sports model which leads to guilt EPS for the greatest number. Incidentally, Pasquier and Paulmaz (2007) reported that sports valid champions, the best; sport accepts those with medium level allows the affirmation of its pseudo-democratic policy and contributes to the massive power of hedonistic axes unanswered. By simply a logical consequence, sport excludes "dummies" who find themselves in a system of domination.

Similar results were obtained in boys where those in the experimental group have a global self-esteem significantly reduced compared to that of the control group (24.70 \pm 2.44 vs. $36.64 \pm 0.76 ; P<0.001)$ (Table 2). This low value of the global self-esteem of boys in the experimental group is in close connection with physical activity and bad conduct inappropriate to have negative effects on self-esteem. For cons, the high value of the global self-esteem of boys in the control group is probably due to the physical activity associated with positive body image having a positive impact on the physical and psychological wellbeing. In terms of behavior, physical activity is responsible for a general well-being, a decrease in aggression (Vigneron, 2005).

The physical value of boys in the experimental group was significantly lower compared to that of their counterparts in the control group (21.86 \pm 1.38 vs. $27.72 \pm 1.74 ; P<0.001)$ (Table 2). These results are explained by the short duration of practice, the menu reduced by APSA, using non critical of teachers, lack of student support by parents in the commitment regarding the experimental group.

The boys in the experimental group were significantly weaker than the control group (13.44 \pm 1.21 vs. 20.74 \pm 1.65 ; $P<0.001$ ) (Table 2). The lower self-esteem in relation to the strength of boys in the experimental group was due to the stagnation of technique during motor learning in pubertal boys havesaid Thibault and al. (Op. cit.). Which induces a feeling of physical disability can lead to the reduction of motivational values include: the loss of self-esteem associated with physical force. Indeed, the value of the force decreases at puberty because of the low duration of APSA practice that reduces the trainability. However, the trainability of strength improves without breaking into regular work conditions (minimum 48 hours of regular interval of time between lessons) (Billat, 2000), high-intensity activity may induce muscle hypertrophy transitional accompanied by hyperplasia of muscle fast twitch fibers, capable of quickly extracting $\mathrm{Ca}^{2+}$ and degrade ATP and whose contraction possible to exert a force (and Costill Wilmore, 1998). These regularity conditions, duration and intensity were not met in the experimental group establishments with 45 minutes weekly EPS is 167 heures and 15 minutes interval between lessons, the reduced number of repetitions, the low work intensity... can not afford muscle adaptations to exercise, to improve the strength and the estimation of its capacity. 
The boys in the experimental group show endurance value significantly less compared to that of the control group (17.18 \pm 1.57 vs. $25.59 \pm 2.41 ; P<0.001)$ (Table 2$)$. This is understandable in that the physical endurance quality is quite difficult because it requires great physical and emotional investment on the part of the experimental group students. In addition, some students often feel abandoned, so our experimental group of students note the difficulty of the activity. In addition, the passion is an engine for the man as well as the race is an engine for the runner, most of the experimental group students do not wish to continue as long as possible. It denotes a weak home want to go higher, to be stronger, to go further. The reason lies in the fact that endurance activities are where they will look to get many satisfactions from a significant energy expenditure and multiple physiological disturbances. The low values of global self-esteem, physical value, the less strength and reduced endurance of boys in the experimental group can affect athletic skill.

The athletic skill of the boys in the experimental group is less developed compared to that of their counterparts in the control group (15.83 \pm 4.34 vs. $21.13 \pm 2.67 ; P<0.001)$ (Table 2$)$. The athletic skill less developed in boys in the experimental group is linked to non-adaptive motivational strategies. In this regard, Famose (2009) identified non-adaptive motivational strategies responsible for reducing motor learning, particularly anticipatory strategies (defensive pessimism, the moral value of doing nothing) and reactive strategies (the self-affirmation, strategies attributionnelles self-indulgence, the lowering or raising the value of the task).

This sporting competence least developed among boys in the experimental group may also be due to limitations of the teaching learning process. It was reported here that the choice of the difficulty of the task does not develop various skills, to experience the success of students, encourage them to adaptive causal attributions and administer not reflected sporting events by significant others (Famose, Op. cit.).

The disengagement of boys in the experimental group was significantly greater than that presented by their counterparts in the control group (7.93 \pm 1.25 vs. $0.64 \pm 0.76 ; P<0.001)$ (Table 2). This major withdrawal of boys in the experimental group is probably related to the loss of motivation especially the values during the tasks which follow the tainted with imperfections. These results are contradictory to those obtained by Choquet and Ledoux (1994) which inform that motivation directs and organizes the selective behavior of individuals. Thus she brings to engage in a task and to persevere. It regulates energy and the amount of effort required to achieve a satisfactory level of achievement in the subject.

This withdrawal could also be related to the low estimation of own skills of the subject. Indeed, an individual who does not feel competent disengages in learning activities. The disengagement persists in tasks with difficulties and raising doubt in combination with the inability to success (Choquet and Ledoux, Op. Cit.).

The results of this study also indicate that the global self-esteem of girls in the control group was significantly higher than that of boys ( $40.40 \pm 1.40$ vs. $36.64 \pm 0.76 ; P<0.001)$ (Table 3$)$. This high value of the global self-esteem of girls in the control group may be determined by the overall appearance of their bodies. Indeed, attending largely consular schools, these girls greatly enjoy and have a good opinion of themselves. Incidentally, Harter, quoted by Famose (2005) showed that there is a link between physical appearance and self-esteem $(+0.70 \leq \mathrm{r} \leq+0.80)$. Seidah (op. cit) has notified the change of his own physical appearance takes prevalence over other predictors of areas esteem.

The girls in the control group had significantly reduced values compared to that of boys of the same group in that respect the physical capacity (20.40 \pm 1.86 vs. $27.72 \pm 1.74)$, strength (16.41 \pm 2.58 vs. $20.74 \pm 1.65)$, endurance $(20.21 \pm 1.17$ vs. $25.59 \pm 2.41)$ and athletic competence $(20.40 \pm 0.49$ vs. $21.13 \pm 2.67)(P<0.001)$ (Table 3). This reduced value of the physical value of the girls in the control group is probably dependent on the undervaluation and the underestimation of the capacity (and potential) to succeed in a physical activity by women, as a young age. It was generally established for this purpose that the physical capabilities of women are lower than those of men (Thorel \& David, 2011).

These girls in the control group were significantly more disengaged than those in the experimental group (1.41 \pm 0.49 vs. $0.64 \pm 0.76 ; P<0.001$ ) (Table 3 ). This greater disengagement of girls to boys in the control group depends on a low encouragement for girls to participate actively, to adjust their mode of travel to different environments to reduce the gap with boys (Zimmerman \& Reavil, 1999).

In the experimental group, the overall estimated value of self is significantly higher than that of boys (37.82 \pm 2.52 vs. $24.70 \pm 2.44 ; P<0.001$ ) (Table 4). This high value of global self-esteem of girls in the experimental group is determined by the fact that EPS, physical appearance becomes a matter of concern for them especially with puberty. Thus, the impact on self-esteem at this time is obviously greater than at any other period of life. And the fact of acquiring a healthy body image is a real step in the journey towards maturity (Coupey, 1995). 
By cons, males of this experimental group had significantly higher values compared to those of girls in the same group with regard to the physical value $(21.86 \pm 1.38$ vs. $15.05 \pm 1.25)$, strength $(13.44 \pm 1.21$ vs. $11.91 \pm$ 3.93) and endurance $(17.18 \pm 1.57$ vs. $16.10 \pm 1.56)(P<0.001$; Table 4$)$. These results reflect a strong physical ability of boys is linked to the accession of teachers to gender norms and the creation of stereotypes (Couchot-Schiex, 2005; Cloes et al., 1998).

However, the athletic skill estimated by girls is significantly higher than the value estimated by males (19.54 \pm 1.74 vs. $15.83 \pm 4.34 ; P<0.001$ ) (Table 4). These results are indicative of the perception of social reality. Indeed, the sport began to be inversely correlated to sex insofar as women now play football and other sports previously reserved for men.

Anyway, the girls in the experimental group were significantly more disengaged than their male colleagues (10.20 \pm 1.26 vs. $7.93 \pm 1.25 ; P<0.001)$ (Table 4). This disengagement would be a function of age. Indeed, DUGAL et al. (2005) through an analysis from an evolutionary perspective, meant that the disengagement process, initiated mainly in the transition from primary to secondary, continues throughout adolescence and into adulthood.

The results of this study indicate what esteem global self-girls of the control group is significantly more important to the boys $(40.40 \pm 1.40 \mathrm{vs.} 36.64 \pm 0.76 ; P<0.001)$ (Table 5). This high value of self-esteem overall girls in the control group can be specified by the overall appearance their body in relation with their school environment. It is generally ESTABLISHED that self-esteem is inextricably linked to self-assessments in the area of physical appearance (Famose, 2005). The girls group presentent witness physical value significantly compared with disabilities. The group of same boys. $(20.40 \pm 1.86$ vs. $27.72 \pm 1.74 ; P<0.001)$ (Table 5). This value reduced physical value of adolescent girls is the control group without doubt dependent on the undervaluation and the underestimation of the capacity to succeed in a physical activity by women. In fact, the morphologies opportunities of women compared to less these are men (Thorel \& David, 2011).

The girls in the control group were significantly weaker than boys of their group (16.41 $\pm 2.58 \mathrm{vs.} 20.74 \pm$ 1.65; $P<0.001$ ). This reduced strength of the girls in the control group could be explained by the self-esteem in relation to gender. The results related to gender have better self concept among boys than girls, especially for scales "sports skills", "fitness" and "strength") (Whitehead \& Corbin, 1997).

The estimate of the endurance of girls in the control group was significantly lower than that of boys of the same group (20.21 \pm 1.17 vs. $25.59 \pm 2.41 ; P<0.001)$ (Table 5). This lower estimate of the endurance could be dependent on the sex influence on the practice frequency. Indeed, Delignieres et al. (1993) obtained results showing the low score of estimating endurance by female subjects compared to those of male ( $7.47 \pm 1.79$ vs. $8.34 \pm 1.87$ ) in relationship with sport frequency.

Waiting for the athletic skill is significantly lower among girls in the control group compared to that of boys in their group $(20.40 \pm 0.49$ vs. $21.13 \pm 2.67 ; P<0.001)$ (Table 5$)$. We explains this by the inequalities that persist in the field of sport and physical education (Fraisse, 1996).

Similar results were also obtained in the experimental subjects with a greater value of global self-esteem of girls than boys (37.82 \pm 2.52 vs. $24.70 \pm 2.44 ; P<0.001$ ) (Table 6). This high value of global self-esteem is also related to the fact that in determining the level of self-esteem is perceived appearance that matters, not the objective corpulence that we can logically infer a relationship between (Tetard and al., op. cit.). Modifying his own physical appearance takes prevalence over other predictors of self-esteem domains (Seidah, op. cit).

However, boys in the experimental group have strong values of self-esteem in its physical dimension compared to girls of the same group, including the physical value (21.86 \pm 1.38 vs. $15.05 \pm 1.25)$, strength (13.44 \pm 1.21 vs. $11.91 \pm 3.93)$, endurance $(17.18 \pm 1.57$ vs. $16.10 \pm 1.56)(P<0.001)$ (Table 6$)$. This stronger physical value boys depends on gender and age. In this regard, the statistics on athletic performance (jumps, runs, throws) college kids and schoolgirls, indicate that girls performance could cap to 13 years while those boys would rise up to 17 years (Davisse, 2000).

However, the athletic skill of the girls in the experimental group was significantly higher than that of their male counterparts $(19.54 \pm 1.74$ vs. $15.83 \pm 4.34)(P<0.001)$ (Table 6). This estimate of the highest sporting authority finds justification in social reality. Indeed, the diversity of the practice of physical and sporting activities such as football, triple jump, volleyball, ... one hand and approximation performance of girls to boys in swimming and the other sprint are probably responsible for the results obtained in this study.

Anyway, the disengagement of the girls in the experimental group EPS is predominant than boys of this group $(10.20 \pm 1.26$ vs. $7.93 \pm 1.25)(P<0.001)$ (Table 6). This preponderance is linked to inequalities that persist in 
the field of sport and physical education. Indeed, sports practices are structured by gender relations and this at different levels: in terms of access to sport in general, rather than staging of masculinity, but also in certain sectors excluding women (Fraisse, 1996).

In short, what should be learned from this study is that the low value of self-esteem is a psychological factor of disengagement in EPS for students of Catholic Humanities Kinshasa. However, the weaknesses of this study lies in not taking into account the dynamics of self-esteem in the teaching/learning of the EPS. Thus, special attention directed towards an educational intervention focused on the dynamics of self esteem can it induce student engagement such humanities Catholic Kinshasa?

\section{Conclusion}

This study has demonstrated the overall estimated value of self, the physical capacity and the most important sporting competence of the control group compared to subjects in the experimental group, a larger disengagement in the control group compared to those in the experimental group among both girls and boys. She also showed a predominant value of self-esteem overall girls than boys in both groups. However, the boys of both groups feel that they have a stronger physical ability than that of girls, while the expectation of athletic skill is controversial. Indeed, the boys in the control group consider themselves sportingly more competent than girls, while the opposite was found in the experimental group. Disengagement is significantly higher among girls than boys in both groups. The results of this study suggest that the low value of self-esteem induces a greater disengagement EPS for students of Catholic schools in Kinshasa.

\section{References}

Atikleme, K. (2002). Swimming Teaching Program in Colleges: Constraints and Production Conditions. The View of the Teaching Anthropology. Doctoral Thesis, Joseph Fourier University of Grenoble I.

Baumeister, R. F., Tice, D. M., \& Hutton, D. G. (1989). Self-Presentational Motivations and Personality Differences in SelfEsteem. Journal of Personality, 57, 547-579. http://dx.doi.org/10.1111/j.1467-6494.1989.tb02384.x

Billat, V. (1998). Physiology and Methodology of Training: From Theory to Practice Sports (p. 193). Brussels: De Boeck Université.

Billat, V. (2000). Physiology and Methodology of Training: From Theory to Practice Sports (p. 396). Brussels: Oxford University Press.

Choquet, M., \& Ledoux, S. (1994). Teenagers: National Survey. Paris: Edition INSREM.

Cloes, M., Demblon, S., Pirottin, V., Ledent, M., \& Pierron, M. (1998). Traitement différencié des élèves en Education physique: Identifier les effets de l'intervention en motricité humaine. Actes du colloque AFRAPS-Ed Pim.

Couchot-Schiex, S., \& Trottin, B. (2005). Interactions Student Teachers: Variation by Sex and Gender. In G. Cogerino, Ed., Girls and Boys in EPS (163-182). Paris: Edition Magazine EPS.

Coupey, S. (1995). Pratiques d'Education Physique et Sportive au corps: Différence des performances entre filles et garçons.

Davisse, A. (2000). Prise en compte de la diversité des publics dans un groupe mixte d'EPS. Communication sur le thème de la diversité des publics: Quels apprentissages en EPS? Académie Poitiers, Mars.

Delignieres, D., Deschamps, T., Legros, A., \& Caillou, N. (1993). A Methodological Note on Non-Linear Time Series Analysis. In Collins and De LUCA, Eds., Open- and Closed-Loop Model a Statistical Artifact? Journal of Motor Behavior, 35, 86-96.

Derimay, E. (2006). Building Your Feminine or Masculine Identity in a Mixed Physical Education. EPS Notebooks, 33, 36.

Edwards, P. (2002). Self-Esteem, Sport and Physical Activity. Canadian Association the Advancement of Women and Sport and Physical Activity.

Famose, J.-P. (2005). Les causses d'une basse estime de soi chez les collégiens et les lycéens. In actes du forum AEEPS 2005 L'EPS, c'est bon pour la santé.

Famose, J.-P., \& Bertsche, J. (2009). Self-Esteem: An Educational Controversy. EPS Review 338. Paris, PUF.

Famose, J.-P., \& Guerin, F. (2002). Self-Awareness. Paris: Armand Colin.

Fraisse, G. (1996). La différence des sexes. Paris: PUF.

Messer, B., \& Harter, S. (1986). Manual for the Adult Self-Perception Profile. Denver, CO: University of Denver.

Ninot, G., Delignières, D., \& Fortes, M. (2000). L'évaluation de l'estime de soi dans le domaine corporel. Revue STAPS, 53, 
35-48.

Pasquier, \& Paulmaz, G. E. (2007). Valuing Learning a: An Emancipatory Aim. Equality Unjust and Just Inequality. The Notebooks of EPS, 35, 19.

Sales-Wuillemin, E. (2006). Methodology of the Survey. In Bromberg, \& A. Trognon (Eds.), 1. Social Psychology (pp. 4577). Paris: PUF.

Tetard, S. C., \& Scanf Ferrand, C. (2004). Physical Self-Esteem Concept in Adolescents through the Comparison of a Sports Population GR and Unsportsmanlike. Research and Innovation Centre in Sport, Social and Scientific Laboratory, Université Lyon I.

Thibault, H., Duche, P., \& Meyer Peresds, M. G. (2010). Physical Activity and Obesity in Children: Basis for an Appropriate Prescription. Ministry of Health, Youth, Sports and Associative Life of the French Republic.

Thorel, S., \& David (2011). La mixité en EPS: Pluralité des approches. Ecole Nationale Supérieure de Cachan. GEDIAPS, Université de Paris 12 CRETEL.

Troadec, K. (2002). Self Attributionnelles Strategies Complacency among Tennis Players. Doctoral Thesis, Orsay: University of Paris XI.

Whitehead, J.-R., \& Corbin, C.-B. (1997). Self Esteem in Children and Youth: The Role of Sport and Physical Education. In K.-R. Fox (Ed.), The Physical Self (pp. 175-204). Leeds: Human Kinetics.

Zimmerman, J., \& Reavil, G. (1999). Raising Our Athletes Daughters. New York: Doubleday. 


\section{Annexe}

Questionnaire d'évaluation de l'estime de soi.

\begin{tabular}{|c|c|c|}
\hline Item & Code & Intitulé \\
\hline 1. + & EG & J'ai une bonne opinion de moi-même \\
\hline 2. + & VPP & Globalement, je suis satisfait de mes capacités physiques \\
\hline 3. - & E & Je ne peux pas courir longtemps sans m’arrêter \\
\hline 4. + & CS & Je trouve la plupart des sports faciles \\
\hline 5. - & A & Je n'aime pas beaucoup mon apparence physique \\
\hline 6. + & $\mathrm{F}$ & Je pense être plus fort que la moyenne \\
\hline 7. - & EG & Il y a des tas de choses en moi que j'aimerais changer \\
\hline 8. + & VPP & Je suis content de ce que je suis et de ce que je peux faire physiquement \\
\hline 9. - & $\mathrm{E}$ & Je serais bon dans une épreuve d'endurance \\
\hline 10. + & CS & Je trouve que je suis bon dans tous les sports \\
\hline 11. + & A & J'ai un corps agréable à regarder \\
\hline 12. + & $\mathrm{F}$ & Je serais bon dans une épreuve de force \\
\hline 13. - & EG & Je regrette souvent ce que j'ai fait \\
\hline 14. + & VPP & Je suis confiant vis-à-vis de ma valeur physique \\
\hline 15. + & E & Je pense pouvoir courir longtemps sans être fatigué \\
\hline 16. + & CS & Je me débrouille bien dans tous les sports \\
\hline 17. - & A & Personne ne me trouve beau \\
\hline 18. + & $\mathrm{F}$ & Face à des situations demandant de la force, je suis le premier à proposer mes services \\
\hline 19. - & EG & J'ai souvent honte de moi \\
\hline 20. + & VPP & En général, je suis fier de mes possibilités physiques \\
\hline 21. + & E & Je pourrais courir $5 \mathrm{~km}$ sans m’arrêter \\
\hline 22. + & CS & Je réussis bien en sport \\
\hline 23. - & A & Je me trouve moche \\
\hline 24. - & $\mathrm{F}$ & Je suis faible et je n'ai rien dans les muscles \\
\hline 25. + & EG & Je voudrais rester comme je suis \\
\hline 26. + & VPP & Je suis bien avec mon corps \\
\hline 27. - & $\mathrm{E}$ & Je ne suis pas très bon dans les activités d'endurance telles que le vélo ou la course \\
\hline 28. + & CS & Je suis agile et adroit quand je fais du sport \\
\hline 29. + & A & Je n'ai aucun problème pour me mettre en maillot de bain devant les autres \\
\hline 30. - & $\mathrm{F}$ & Je suis moins fort musculairement que la plupart des gens de mon âge \\
\hline
\end{tabular}

\section{Submit or recommend next manuscript to SCIRP and we will provide best service for you:}

Accepting pre-submission inquiries through Email, Facebook, LinkedIn, Twitter, etc.

A wide selection of journals (inclusive of 9 subjects, more than 200 journals)

Providing 24-hour high-quality service

User-friendly online submission system

Fair and swift peer-review system

Efficient typesetting and proofreading procedure

Display of the result of downloads and visits, as well as the number of cited articles

Maximum dissemination of your research work

Submit your manuscript at: http://papersubmission.scirp.org/ 